\title{
敗血症患者に対する免疫グロブリン製剤の短期抗サイトカイ ン効果の検証
}

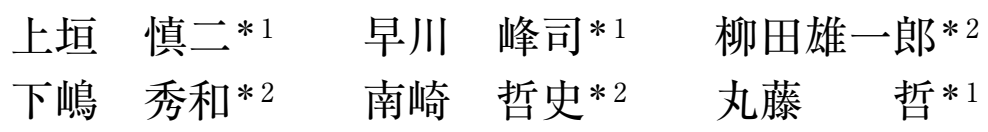

\section{はじめに}

重症感染症に対する免疫グロブリン静注療法 (intravenous immunoglobulin, IVIG) の効果は, 一定の評価 を得ている1)。その機序は, オプソニン作用, 補体活 性化による免疫溶菌作用, 細菌が産生する毒素やウイ ルスに対する特異抗体による中和作用などとされてい るが, 明らかでない点も多い。IVIGの抗サイトカイ ン効果に関してはtumor necrosis factor- $\alpha$ (TNF- $\alpha$ ) や interleukin-6 (IL-6) を投与前後で比較し IL-6の低下 作用を報告したものや，動物モデルでの high mobility group box 1 (HMGB-1)の低下を報告したものが散見 される 2) 7)。TNF- $\alpha$, IL-6 は感染早期に変動するマー カーであるにもかかわらず，ヒトを対象とした過去の 報告はいずれも検討期間を 3 日間と, 比較的長時間に 設定している。今回, 我々はIVIGの作用の一つであ る抗サイトカイン効果に関して, 短時間の変化に着目 して検討を行った。

\section{対象と方法}

本研究は北海道大学病院と KKR札幌医療センター の倫理委員会に承認され，患者または患者家族へのイ ンフォームドコンセントを得た後に施行した。来院時 に重症敗血症もしくは敗血症性ショックと診断し, 免 疫グロブリン製剤を使用した重症感染症症例を対象と した。敗血症および敗血症性ショックの診断は American College of Chest Physicians/Society of Critical Care Medicineの合同会議の定義に従った ${ }^{8)}$ 。 16 症例 (男性 10 例, 女性 6 例) を対象とし, 平均年齢は
69.9 歳であった。感染源は重症肺炎6例, 腹部汎発性 腹膜炎 4 例, 急性上腸間膜動脈閉塞後の腹膜炎 2 例, 尿 路感染症4例であった。Sequential organ failure assessment (SOFA) scoreの平均值は10.9点, Acute Physiology and Chronic Health Evaluation (APACHE) II scoreは27.9点であった。全症例で systemic inflammatory response syndrome (SIRS)の 診断基準の 3 項目以上を満たし, 敗血症もしくは敗血 症性ショックの状態であった。

IVIGは診断確定後 24 時間以内に投与を開始した。 インタクト型の非スルホ化製剤 $5 \mathrm{~g}$ を 1 時間で投与し, 24 時間間隔で 3 回投与した。初回投与の 1 時間前, 投与直前, 投与直後, 投与 1 時間後に採血し, 速やかに 遠心分離して血漿を $-80^{\circ} \mathrm{C}$ で保存した。各検体で TNF- $\alpha$ (健常人基準值 $1.79 \mathrm{pg} / \mathrm{m} l$ 以下), IL-6 (健常人 基準值 $2.41 \mathrm{pg} / \mathrm{m} l$ 以下), HMGB-1濃度を測定した。 検体採取時間に関しては, 各種サイトカインの投与前 值を対照值と仮定するために, 投与 1 時間前, 投与直 前の 2 時点で採血を行った。TNF- $\alpha$ はchemiluminescent enzyme immunoassay 法 (QuantiGlo Human TNF- $a$ Immunoassay kit, R\&D Systmens Inc., USA), IL-6 は enzyme immunoassay 法 (QuantiGlo Human IL-6 Immunoassay kit, R\&D Systems Inc., USA), HMGB-1 はenzyme-linked immunosorbent assay 法 (HMBG-1 ELISA kit II , 株式会社シノテスト) により測定した。対照群は設定せず，投与 1 時間前と 投与直前の值を対照值として投与後の值を検討した。

統計学的検討は, 反復測定による一元配置分散分析 を施行し, 有意差を認めた場合は post hoc testとして

\footnotetext{
*1 北海道大学病院先進急性期医療センター

( T 060-8638 北海道札幌市北区北 15 条西 7 丁目)

*2 KKR札幌医療センター集中治療センター 
(a)

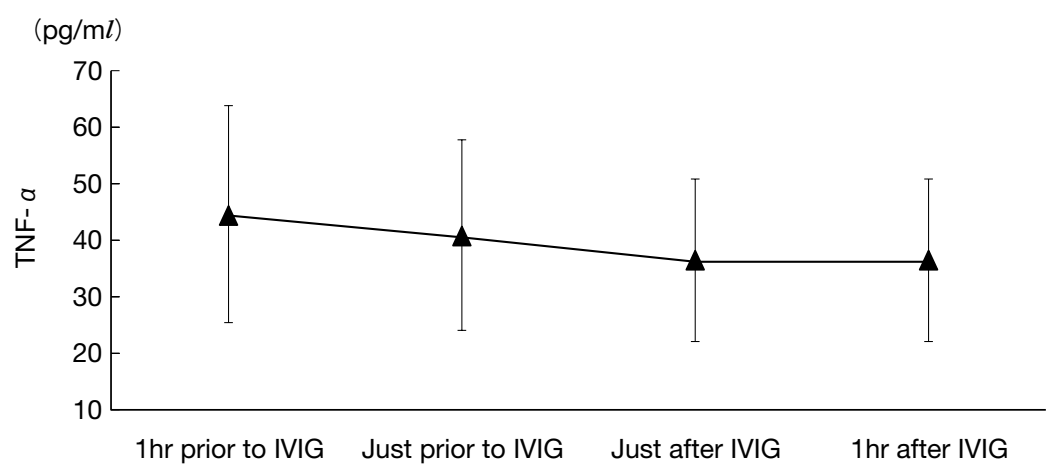

(b)

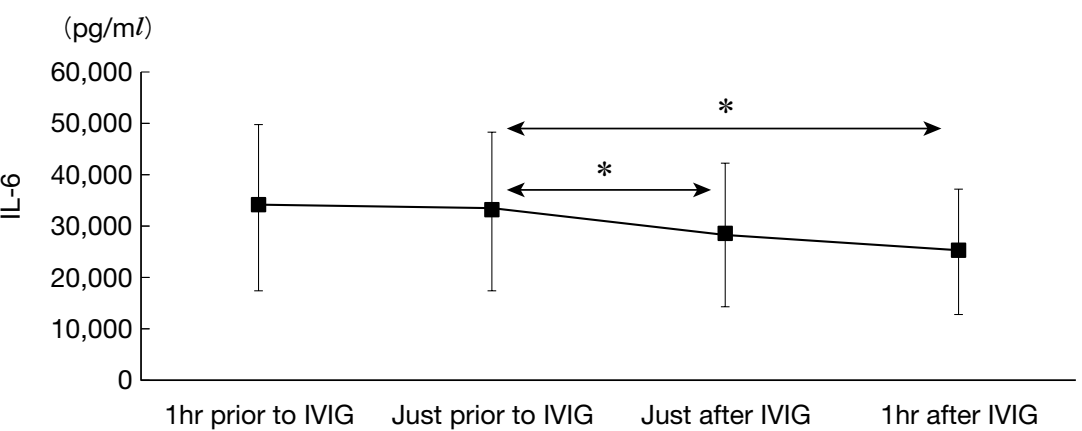

(c)

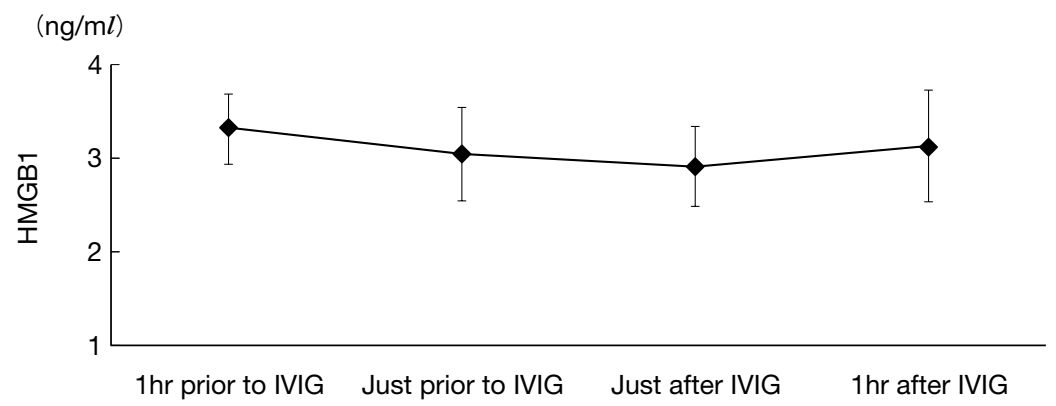

Fig. 1 Changes in plasma levels of TNF- $\alpha$ (a), IL-6 (b), and HMGB-1 (c)

While the level of IL- 6 was significantly decreased at $1 \mathrm{hr}$ and $2 \mathrm{hrs}$ after the administration of IVIG, no changes were observed in the level of TNF- $\alpha$ and HMGB-1.

HMGB-1, high mobility group box 1; IL-6, interleukin-6; IVIG, intravenous immunoglobulin; TNF- $\alpha$, tumor necrosis factor- $\alpha$.

$* P<0.05$.

Bonferoniの方法を用いた。測定結果は平均值士標準 誤差で示し, $P<0.05$ を有意差ありとした。

\section{結 果}

測定項目の経時的推移を Fig. 1に示す。IL-6 は投与 1 時間前と投与直前で差を認めなかったが, 投与直前 と比較して投与直後と投与 1 時間後で低下していた (Fig. 1b)。TNF- $a$ と HMGB-1 は経時的変化を示さな かった (Fig. 1a, c)。

\section{考 察}

IVIGの抗サイトカイン効果に関する最近の報告を Table 1にまとめた。IVIG投与により IL-6 は殆どの報
告で低下し, HMGB-1 は全ての報告で低下していた。 TNF- $\alpha$ は変化がないとの報告が多かった。これらの うち，ヒトを対象としたIVIGの抗サイトカイン効果 に関し検証した報告は，採血前後の期間が全例で 3 日 であったのに対し, 動物モデルでは 12 時間以内であっ た。サイトカインは非常に短時間で劇的に変動するこ とを考慮し, 測定期間中の種々の薬剤による影響を可 及的に少なくするために, 我々はIVIG投与後短時間 での検証を行った。また本研究では, 投与 1 時間前と 投与直前の值を対照值と仮定したために, 非投与群の ような対照群は設定しなかった。

IVIGの抗サイトカイン作用の機序として, 製剤中 に含まれる抗サイトカイン抗体による中和作用3)や, 
敗血症に対するIVIGの短期抗サイトカイン効果

Table 1 Recent reports of the change in the cytokine levels by IVIG

\begin{tabular}{|c|c|c|c|c|c|c|c|c|}
\hline & & Immnoglobulin & $\mathrm{N}$ & Subject & Duration & IL-6 & TNF- $\alpha$ & HMGB-1 \\
\hline Shibata, et al ${ }^{2)}$ & 1996 & Nonsulfonated & 21 & Human & 3 days & $\downarrow$ & $\rightarrow$ & \\
\hline Kimura, et al ${ }^{3)}$ & 1996 & Both & 33 & Human & 3 days & $\downarrow$ & & \\
\hline \multirow[t]{3}{*}{ Suzuki, et al ${ }^{4)}$} & 2004 & Sulfonated & 7 & Human & 3 days & $\downarrow$ & & \\
\hline & 2006 & Nonsulfonated & 4 & Human & 3 days & & & $\downarrow$ \\
\hline & 2008 & Both & 53 & Human & 3 days & & & $\downarrow$ \\
\hline Asakura, et al ${ }^{5)}$ & 2006 & Nonsulfonated & 12 & Rat & $1,5 \operatorname{hour}(\mathrm{s})$ & $\downarrow$ & $\rightarrow$ & \\
\hline Etou, et al ${ }^{6)}$ & 2007 & Both & 12 & Mouse & $1,4,8 \operatorname{hour}(\mathrm{s})$ & $\rightarrow$ & $\rightarrow$ & \\
\hline Hagiwara, et al 7) & 2008 & Nonsulfonated & 24 & Rat & $3,6,12$ hours & $\downarrow$ & $\downarrow$ & $\downarrow$ \\
\hline
\end{tabular}

IVIG, intravenous immunoglobulin; HMGB-1, high mobility group box 1; IL-6, interleukin-6; TNF- $\alpha$, tumor necrosis factor- $\alpha$.

サイトカインを産生する免疫担当細胞の Fc レセプタ を介したサイトカイン産生抑制作用などが報告されて (る2)。本研究では, IL-6 は有意に減少した。本研究 のIL-6 定量法はIL-6 と抗IL-6抗体の複合体を測定す るものではなく, IL-6減少の機序としては, 製剤中の 抗IL-6抗体による中和作用が考えられた ${ }^{3)}$ 。しかし, 製剂中の抗IL-6抗体濃度を調查した報告はなく, IL-6 の減少を抗原抗体反応のみで説明できるわけではな い。臨床的には敗血症で認められる量のIL-6を十分中 和するためには, 少なくとも $2.0 \mathrm{~g} / \mathrm{kg}$ の免疫グロブリ ンが必要であるという報告9もあり, 本邦で使用可能 な投与量での抗サイトカイン効果で臨床効果を期待す ることは困難と考えられる。

TNF- $a$ はIL-6の変動とはやや異なり, 発症早期に血 中濃度は急激に上昇するが, 半減期が短く, 血中濃度 上昇は一相性である。今回我々は, 来院後早期に検討 を施行したが, 感染症発症時期が正確には特定できな かったことがTNF- $a$ の変動を検出できなかった原因 と考える。Hagiwaraらは, 動物実験でIVIGによる HMGB-1 低下を認めたのは 12 時間後である。このよ うな低下のメカニズムに関しては未だ解明されていな いが, IVIGによる直接的効果よりも，TNF- $\alpha$ やIL-6 どの炎症性サイトカインの産生を抑制することによる 二次的な結果によるのでは，と考察している7)。 HMGB-1 は晚期メディエータであり, 来院直後という 感染症の発症早期における短時間の検証であることが HMGB-1 值に変化を認めなかった原因と推測する。ま た，免疫グロブリン製剤内の TNF- $\alpha$, HMGB- 1 に対す る中和抗体の存在とその効果に関する検証を行った報 告は, 検索し得た限り認めなかった。本研究の限界と して, 以下の点が挙げられる。

(1)敗血症の原疾患により結果が異なる可能性

(2)測定時間が短く，晚期メディエータの HMGB-1の 変化を捉えられなかった可能性
(3)対照群の設定がない点

また，近年報告される $1 \mathrm{~g} / \mathrm{kg}$ 以上の大量免疫グロ ブリン投与の効果も検証する必要がある。

\section{まとめ}

IVIGの抗サイトカイン効果を短時間の経過で検証 したところ, IL-6の血中濃度は低下したが, TNF- $a$ と HMGB-1の血中濃度は変化しなかった。

\section{文 献}

1) 正岡 徹, 長谷川廣文, 高久文麿, 他. 重症感染症に対す る抗菌薬との併用療法における静注用ヒト免疫グロブリン の効果. 日加療会誌 2000;48:199-217.

2) 柴田泰史，木村昭夫，西澤健司，他．免疫グロブリン製剂 投与によるサイトカインの変動. 日外感染症研 1996;8: 19-24.

3) 木村昭夫，柴田泰史，西澤健司，他．全身性炎症反応症候 群における免疫グロブリン製郕投与意義の検討. 日救急医 誌 1997:7:307-8.

4) 鈴木秀道, 池田寿昭, 池田一美. Sepsis患者に扔けるサイ トカインの動向と免疫グロブリン投与の影響. ICU と CCU 2004;28:119-24.

5) Asakura H, Takahashi Y, Kubo A, et al. Immunoglobulin preparations attenuate organ dysfunction and hemostatic abnormality by suppressing the production of cytokines in lipopolysaccharide-induced disseminated intravascular coagulation in rats. Crit Care Med 2006;34:2421-5.

6) 江藤 晶, 西山雄一. マウス敗血症モデルに扔ける各種サ イトカインの変動と免疫グロブリン投与の効果. Prog Med 2007;27:1833-7.

7) Hagiwara S, Iwasaka H, Hasegawa, et al. High-dose intravenous immunoglobulin $\mathrm{G}$ improves systemic inflammation in a rat model of CLP-induced sepsis. Intensive Care Med 2008;34:1812-9.

8) American College of Chest Physicians/Society of Critical Care Medicine Consensus Conference: definitions for sepsis and organ failure and guidelines for the use of innovative therapies in sepsis. Crit Care Med 1992;20: 864-74.

9) Svenson M, Hansen MB, Bendtzen K. Binding of cytokines to pharmaceutically prepared human immunoglobulin. J Clin Invest 1993:92:2533-9. 


\title{
Abstract
}

Short-term effects of intravenous immunoglobulin on changes in the plasma levels of cytokines in patients with sepsis

\author{
Shinji Uegaki*1, Mineji Hayakawa*1, Yuichiro Yanagida*2, Hidekazu Shimojima*2, Satoshi Nanzaki*2, \\ Satoshi Gando*1 \\ ${ }^{* 1}$ Division of Acute and Critical Care Medicine, Department of Anesthesiology and Critical Care Medicine, Hokkaido University \\ Graduate School of Medicine \\ *2 Division of Emergency Medicine and Critical Care Medicine, KKR Sapporo Medical Center \\ ${ }^{* 1}$ N17 W5, Kita-ku, Sapporo, Hokkaido 060-8638, Japan \\ *23-40, Hiragishi 1-jo 6-chome, Toyohira-ku, Sapporo, Hokkaido 062-0931, Japan
}

Previous reports have indicated that intravenous immunoglobulin (IVIG) preparation reduces some types of inflammatory cytokines. In the present study, we investigated the short-term and direct effects of IVIG in 16 patients with sepsis. Following the administration of $5 \mathrm{~g}$ of IVIG for 1 hour, we took blood samples immediately following IVIG treatment and at 1 hour after IVIG treatment. Blood samples taken at 1 hour and just prior to IVIG administration were used as controls. While there was no difference between 1 hour before and just prior to IVIG treatment, statistically significant decreases were observed in the levels of interleukin-6 (IL-6) after the administration of IVIG. No significant changes were observed in the plasma levels of tumor necrosis factor- $\alpha$ and high mobility group box 1 . We confirmed the results of previous animal studies. While we reported that the administration of IVIG directly reduces the plasma levels of IL-6 in patients with sepsis, a further prospective study of the anti-cytokine effects following IVIG treatment will be conducted in the near future.

Key words: (1) sepsis, (2) intravenous immunoglobulin, (3) cytokine

J Jpn Soc Intensive Care Med 2011;18:249 252 . 